\title{
Ocular flutter as the first manifestation of Lyme disease
}

向

A 33-year-old man with a history of tick bites presented with bursts of involuntary horizontal conjugate saccades, myoclonic head jerks, and truncal ataxia. A cerebral MRI was normal, and no antineuronal antibodies were found (anti-Hu, anti-Yo, anti-Ri). Despite negative serum antibodies for Borrelia burgdorferi, acute neuroborreliosis was suspected because of lymphocytic mild meningitis (19 white cells $/ \mathrm{mm}^{3}$, protein 0.79 $\mathrm{g} / \mathrm{L}$ ) and apparent intrathecal synthesis of $B$ burgdorferi IgM antibodies (ELISA titers 6.17, normal $<0.3$ ), although false-positive IgM serologies can occur in this setting. Intravenous ceftriaxone treatment resulted in dramatic clinical improvement within a few weeks.

In ocular flutter, saccadic intrusions are purely horizontal (see video), while in opsoclonus-myoclonus, a similar condition, they are multidirectional. ${ }^{1}$ Cerebral MRI studies are usually normal, ${ }^{2}$ lesions involving omnipause neurons in the pons, or the fastigial nucleus in the cerebellum being exceptional.

Supplemental data at www.neurology.org
Jesper Gyllenborg, MD, Dan Milea, MD, PhD, Copenhagen, Denmark

Disclosure: The authors report no disclosures.

Address correspondence and reprint requests to Dr. Jesper Gyllenborg, Department of Neurology, Glostrup Hospital, University of Copenhagen, 57, Nordre Ringvej, DK-2600 Glostrup, Denmark; jesper@gyllenborg.dk

1. Wong AM, Musallam S, Tomlinson RD, Shannon P, Sharpe JA. Opsoclonus in three dimensions: oculographic, neuropathologic and modelling correlates. J Neurol Sci 2001;15:71-81.

2. Peter L, Jung J, Tilikete C, Ryvlin P, Mauguiere F. Opsoclonus-myoclonus as a manifestation of Lyme disease. J Neurol Neurosurg Psychiatry 2006;77:1090-1091. 


\title{
Neurology
}

\author{
Ocular flutter as the first manifestation of Lyme disease \\ Jesper Gyllenborg and Dan Milea \\ Neurology 2009;72;291 \\ DOI 10.1212/01.wnl.0000339491.14474.61
}

This information is current as of January 19, 2009

\section{Updated Information \& Services \\ Supplementary Material \\ References \\ Subspecialty Collections}

Permissions \& Licensing

Reprints including high resolution figures, can be found at: http://n.neurology.org/content/72/3/291.full

Supplementary material can be found at: http://n.neurology.org/content/suppl/2009/01/17/72.3.291.DC1

This article cites 2 articles, 1 of which you can access for free at: http://n.neurology.org/content/72/3/291.full\#ref-list-1

This article, along with others on similar topics, appears in the following collection(s):

All Neuro-ophthalmology

http://n.neurology.org/cgi/collection/all_neuroophthalmology

Bacterial infections

http://n.neurology.org/cgi/collection/bacterial_infections

Myoclonus

http://n.neurology.org/cgi/collection/myoclonus

Information about reproducing this article in parts (figures,tables) or in its entirety can be found online at:

http://www.neurology.org/about/about_the_journal\#permissions

Information about ordering reprints can be found online: http://n.neurology.org/subscribers/advertise

Neurology ${ }^{\circledR}$ is the official journal of the American Academy of Neurology. Published continuously since 1951, it is now a weekly with 48 issues per year. Copyright . All rights reserved. Print ISSN: 0028-3878. Online ISSN: 1526-632X.

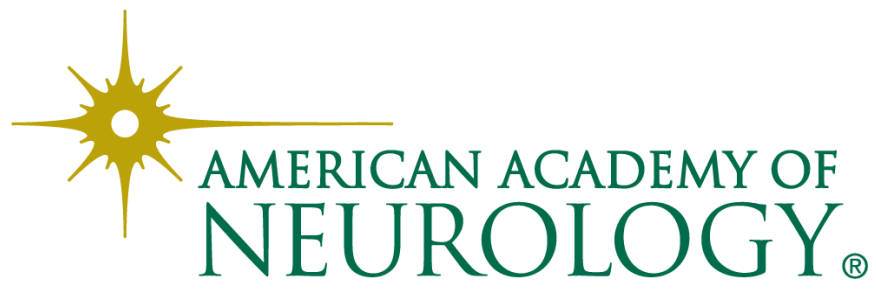

